\title{
Camera-guided Weed Hoeing in Winter Cereals with Narrow Row Distance
}

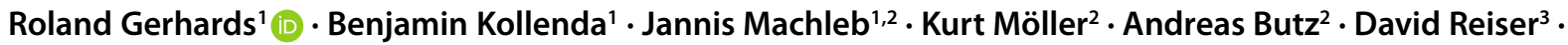 \\ Hans-Werner Griegentrog ${ }^{3}$
}

Received: 3 July 2020 / Accepted: 13 October 2020 / Published online: 29 October 2020

(c) The Author(s) 2020

\begin{abstract}
Farmers are facing severe problems with weed competition in cereal crops. Grass-weeds and perennial weed species became more abundant in Europe mainly due to high percentages of cereal crops in cropping systems and reduced tillage practices combined with continuous applications of herbicides with the same mode of action. Several weed populations have evolved resistance to herbicides. Precision weed hoeing may help to overcome these problems. So far, weed hoeing in cereals was restricted to cropping practices with row distances of more than $200 \mathrm{~mm}$. Hoeing in cereals with conventional row distances of $125-170 \mathrm{~mm}$ requires the development of automatic steering systems. The objective of this project was to develop a new automatic guidance system for inter-row hoeing using camera-based row detection and automatic side-shift control. Six field studies were conducted in winter wheat to investigate accuracy, weed control efficacy and crop yields of this new hoeing technology.

A three-meter prototype and a 6-meter segmented hoe were built and tested at three different speeds in $150 \mathrm{~mm}$ seeded winter wheat. The maximum lateral offset from the row center was $22.53 \mathrm{~mm}$ for the $3 \mathrm{~m}$ wide hoe and $18.42 \mathrm{~mm}$ for the $6 \mathrm{~m}$ wide hoe. Camera-guided hoeing resulted in $72-96 \%$ inter-row and $21-91 \%$ intra-row weed control efficacy (WCE). Weed control was $7-15 \%$ higher at $8 \mathrm{~km} \mathrm{~h}^{-1}$ compared to $4 \mathrm{~km} \mathrm{~h}^{-1}$. WCE could be increased by $14-22 \%$ when hoeing was combined with weed harrowing. Grain yields after camera-guided hoeing at $8 \mathrm{~km} \mathrm{~h}^{-1}$ were $15-76 \%$ higher than the untreated control plots and amounted the same level as the weed-free herbicide plots. The study characterizes camera-guided hoeing in cereals as a robust and effective method of weed control.
\end{abstract}

Keywords Precision weed control $\cdot$ Image analysis $\cdot$ Integrated weed management $\cdot$ Mechanical weeding

Roland Gerhards

gerhards@uni-hohenheim.de

1 Fachgebiet Herbologie, Universität Hohenheim,

70593 Stuttgart, Germany

2 Referat Pflanzenbau, Landwirtschaftliches

Technologiezentrum Augustenberg, Rheinstetten-Forchheim,

Germany

3 Fachgebiet Verfahrenstechnik in der Pflanzenproduktion,

Universität Hohenheim, 70593 Stuttgart, Germany 


\section{Kamera-gesteuertes Hacken in Getreide mit engem Reihenabstand}

\section{Zusammenfassung}

Landwirte haben erhebliche Probleme durch Unkrautkonkurrenz in Getreidekulturen. Ungräser und perennierende Unkrautarten haben sich in Europa deutlich ausgebreitet, hauptsächlich aufgrund der hohen Anteile an Getreide in der Fruchtfolge und der reduzierten Bodenbearbeitung kombiniert mit dem häufigen Einsatz von Herbiziden mit gleichen Wirkmechanismen. Mehrere Unkrautpopulationen in Europa sind resistent gegen Herbizide. Daher sind wirksame alternative Verfahren der Unkrautbekämpfung notwendig. Präzises Hacken könnte dazu beitragen, diese Probleme zu lösen. Allerdings werden Hackverfahren in Getreide bislang hauptsächlich im organischen Landbau eingesetzt bei Reihenweiten von meist mehr als $200 \mathrm{~mm}$. Zum Hacken in konventionell gesätem Getreide mit 125-170 mm Reihenabstand, benötigt man ein automatisches Lenksystem an der Hacke. Das Ziel des Projekts war es, ein neues, Kamera-basiertes System zur automatischen Steuerung der Hacke zwischen den Getreidereihen zu entwickeln. Dazu wurden 6 Feldexperimente in Winterweizen durchgeführt, um die Genauigkeit des Lenksystems, den Bekämpfungsgrad der Unkräuter und die Kornerträge zu untersuchen. Es wurden ein Prototyp mit drei Meter Breite und eine segmentierte Hacke mit sechs Meter Breite gebaut. Die maximale laterale Abweichung von der Reihenmitte lag bei 22,53 mm für die 3-Meter-Hacke und 18,42 mm für die 6-m-Hacke. Kamera-gesteuertes Hacken führte zu einer Unkrautkontrolle von 72-96\% zwischen den Reihen und 21-91\% innerhalb der Reihen aufgrund der Bodenverschüttung. Der Bekämpfungsgrad gegen die Unkräuter war bei $8 \mathrm{~km} \mathrm{~h}^{-1}$ Fahrgeschwindigkeit 7-15\% höher als bei $4 \mathrm{kmh}^{-1}$. Es wurden 14-22\% mehr Unkräuter bekämpft, wenn Hacken mit Striegeln kombiniert wurde. Bei der hohen Geschwindigkeit von $8 \mathrm{~km} \mathrm{~h}^{-1}$ wurden $15-76 \%$ höhere Getreideerträge erzielt als in der unbehandelten Kontrolle und gleiche Erträge wie in der unkrautfreien Herbizidvariante. Die Studie zeigte, dass die Kamera-gesteuerte Hacke in Getreide mit engen Reihenabständen ein robustes und effizientes System der Unkrautkontrolle ist.

Schlüsselwörter Präzise Unkrautkontrolle · Digitale Bildverarbeitung · Integrierte Unkrautbekämpfung · Mechanische Unkrautbekämpfung

\section{Introduction}

Camera-guided hoeing technologies with automatic sideshift control have significantly improved mechanical weed control in crops with row distances higher than $180 \mathrm{~mm}$ such as maize, sugar beet, soybean, sunflower and some vegetables (Tillett and Haugue 1999; Tillet et al. 2002; Griepentrog et al. 2007; Kunz et al. 2015, 2018). Automatic guidance system increased weed control efficacy in sugar beet and soybean by $12 \%$ compared to machine hoeing with manual guidance (Kunz et al. 2015). The authors explain higher weed control efficacy by guiding inter-row blades closer along crop rows and stronger burial of weeds with soil due to higher driving speed. Row guidance was realized based on row detection with a camera or using RTKGNSS positioning (Tillett et al. 2002; Soegaard and Olsen 2003; Griepentrog et al. 2007). Current automatic steering systems have an accuracy of $\pm 4 \mathrm{~cm}$ deviation from a centre line at a driving speed of up to $10 \mathrm{~km} / \mathrm{h}$ (Melander 2006; Griepentrog et al. 2007).

However, cereals are mostly sown in narrow row distances of 125-170 mm (Gerhards 2010). Wide distances are only practiced in organic farming. Grain yield is significantly lower in cropping systems with row distances wider than $170 \mathrm{~mm}$ compared to $125-150 \mathrm{~mm}$ (Lötjönen and Mikkola 2000; Mülle and Heege 1981; Håkansson 1984). In addition to that, weed competition was higher at wider row distances (Blair et al. 1997) compared to conventional row distances of $125-150 \mathrm{~mm}$ (Rasmussen and Svenningsen 1995; Hammarström et al. 1993). This is probably a consequence of lower competitive ability of the crop in early growth stages and later canopy closure at wide row spacing.

Weed harrowing is the common mechanical weeding practice in cereals. Harrowing can be applied independently of the row distances across the whole area (Rasmussen and Svenningsen 1995). However, weed control efficacy (WCE) and selectivity varies significantly between year and location. Field studies carried out in Norway in spring wheat showed a WCE of $47 \%$ after post-emergence harrowing (Brandsaeter et al. 2012). Rasmussen et al. (2008) achieved 80-90\% WCE against annual broad-leaved weeds in spring cereals. However, harrowing is less effective against larger weeds, annual grasses (e.g. Alopecurus myosuroides Huds) and perennial weeds (e.g. Cirsium arvense L., Elymus repens L.) (Melander et al. 2003). Abundance of those difficult-to-control weed species including grass weeds (Alopecurus myosuroides, Apera spica-venti, Lolium multiflorum, Poа аппиа) and perennial weed species (Cirsium arvense, Elymus repens) have increased in European cereal production systems during the last decades. This was mainly due to higher percentages of cereal crops in crop rotations and less intensive soil tillage operations (Massa et al. 2013). 
A promising alternative to weed harrowing in cereals is hoeing with camera-guidance systems adjusted to narrow row distances. Hoeing blades control larger weeds and grass-weeds and the risk of crop damage is lower than for harrowing because hoeing is restricted to the inter-row area (Lötjönen and Mikkola 2000). Weed hoeing is less sensitive to timing of the treatment because even larger weeds will be uprooted (Melander et al. 2003). Weed control efficacy of hoeing is less affected by soil moisture and soil type than harrowing (Rasmussen 2004; Rasmussen and Ascard 1995) because weeds are uprooted by the hoeing blades, whereas the harrow covers weeds with soil and uproots only smaller weeds. This requires dry and loose soil conditions. Efficacy of weed hoeing is rather high. Dierauer and StöpplerZimmer (1994) found that $90 \%$ of the weeds between the crop rows were uprooted and $75 \%$ of the weeds within the crop row were covered by soil after two passes of hoeing in maize and peas. Melander et al. (2003) suggested that a higher speed could increase the soil coverage of intra-row weeds and thus may lead to higher weed suppression.

The focus of this study was to develop an automatic guidance system for weed hoeing in cereals with narrow row distances. The objective was to develop a hoe with hydraulic side-shift control combined with a camera-based row detection system for cereals with partly overlapping leaves in the inter-row area. It was tried to increase accuracy of row guidance to $\pm 20 \mathrm{~mm}$ to achieve higher WCE and avoid crop damage when the hoeing blades were steered at a distance of $25 \mathrm{~mm}$ along cereal rows. Crop soil cover and WCE were investigated in winter wheat at $150 \mathrm{~mm}$ row spacing and different speeds. It was hypothesized that
WCE and grain yields are higher at $8 \mathrm{~km} \mathrm{~h}^{-1}$ driving speed compared to conventional hoeing speeds of $4 \mathrm{~km} \mathrm{~h}^{-1}$. We further hypothesize that grain yields of the hoeing treatments are higher than in the untreated control and equal to the herbicide treatment. The third hypothesis was that WCE increased when hoeing was combined with harrowing.

\section{Materials and Methods}

\section{Camera-guidance of the Hoe}

Row detection is implemented in a real-time system for automatic steering of the no-till sweeps in the inter-row with a distance of $25 \mathrm{~mm}$ to the crop rows. Pictures are continuously taken and analysed by an RGB-camera connected to a controller. The camera is mounted at the tool bar of the hoe scanning diagonally forward on 4-6 crop rows. Images are segmented into green plants and background consisting of soil and mulch. In the regions of highest green pixel densities tracking of cereal rows is done by an extended Kalman filter (Tillet et al. 2002). This guarantees a fast row detection even if the crop leaves partly overlap in the interrow area. The camera provides robust row detection under most lightning conditions. Artificial light improves the quality of row detection. A hydraulic side-shift control system was implemented to automatically move the no-till sweeps exactly in the centre between two crop rows. Positions of the sweeps were adjusted five times per second.
Fig. 1 Hoe tool arrangement of the $3 \mathrm{~m}$ camera guided hoe (B. Kollenda)

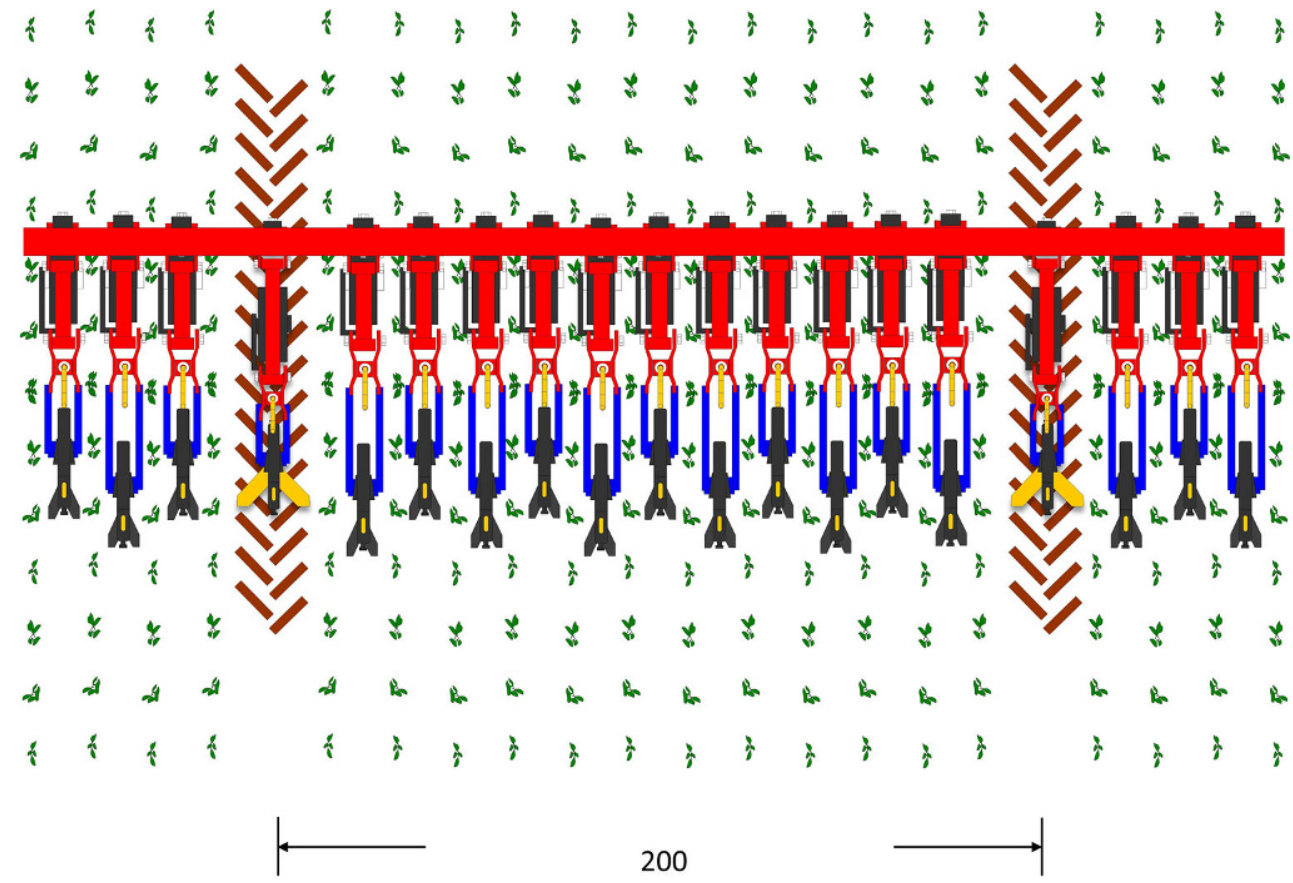




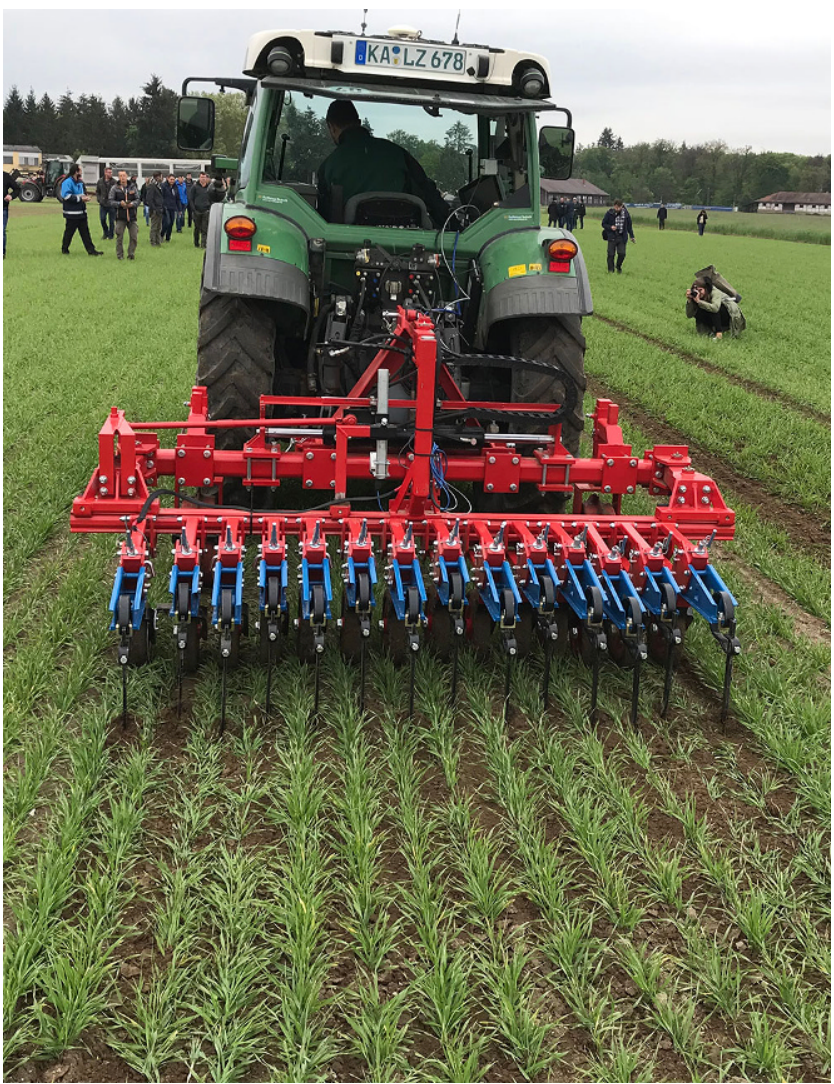

Fig. 2 Camera-guided hoeing in winter wheat with a width of $3 \mathrm{~m}$ and a row distance of $150 \mathrm{~mm}$ (R. Gerhards)

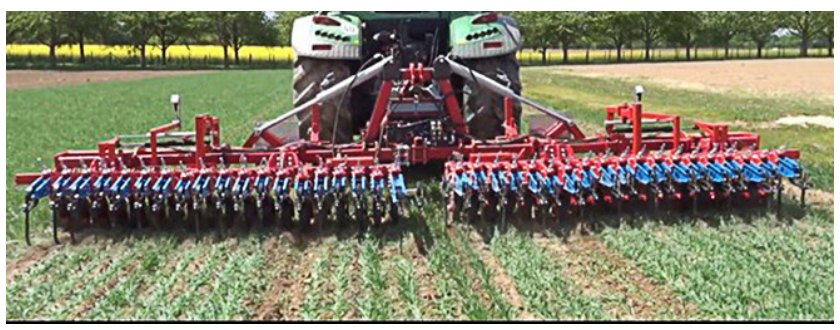

Fig. 3 Camera-guided hoeing in winter wheat with a segmented hoe of $6 \mathrm{~m}$ width and a row distance of $150 \mathrm{~mm}$ (B. Kollenda)

\section{Hoeing Prototypes}

Two hoeing prototypes were implmented for the field experiments, one with $3 \mathrm{~m}$ width and one with $6 \mathrm{~m}$ width separated into two independent hoeing units of $3 \mathrm{~m}$ width fixed on one foldable frame (Figs. 1, 2 and 3). The width of $3 \mathrm{~m}$ was necessary because this is the common width of sowing machines on farms in Southern Germany. The $6 \mathrm{~m}$ wide hoe allows a higher labor efficiency. The hydraulic side-shift system is presented in Fig. 4. The hydraulic system was equipped with two manual flow-control valves "FT 257/5" (F.lli Tognella Spa, Somma Lombardo, Italy) to finetune the oil pressure provided by the tractor. The flow control valves were attached between the solenoid valves and the hydraulic cylinder. The Tillett et al. (2002) controller unit was mounted under the three-point hitch frame to protect the unit from damage during operations and transport. The camera was mounted below the center pivot arm of the tower. Parallelograms (Argus, K.U.L.T. Vaihingen/Enz, Germany), were used for every row to adjust for variable elevations of the soil (Fig. 2). The positions of the equipment enabled accurate tool guidance. No-till sweeps with $100 \mathrm{~mm}$ width were used for $150 \mathrm{~mm}$ row distance. Sweeps were fixed on the parallelograms. $160 \mathrm{~mm}$ no-till sweeps were mounted in the tracks of the tractor wheels (Fig. 1).

\section{Study Sites and Setup of Field Trials}

Four field experiments were conducted in 2019 in winter wheat, cv. Argument to test the new camera-guided hoeing technology with a row distance of $150 \mathrm{~mm}$ and driving speeds of 4,6 and $8 \mathrm{~km} \mathrm{~h}^{-1}$. Two experiments were located at the experimental research station in Hohenheim $(\mathrm{HOH})$ and two at Ihinger Hof (IHO).

The soil texture is a clayey loam at both locations. Winter wheat was sown with 400 seeds $\mathrm{m}^{-2}$ at a depth of $30 \mathrm{~mm}$ in the end of October 2018 using a Deppe plot seeder (AgrarMarkt Deppe, Bad Lauterberg-Barbis, Germany) at IHO and a Hege plot seeder (Zürn Harvesting, Schöntal-Westernhausen, Germany) at $\mathrm{HOH}$. Hoeing and harrowing was
Fig. 4 Hydraulic steering frame. (a) Stationary part (b) Supporting wheels, (c) Synchronous cylinder, (d) Tie rod, (e) Tower arm, (f) Tool bar (B. Kollenda) (a)

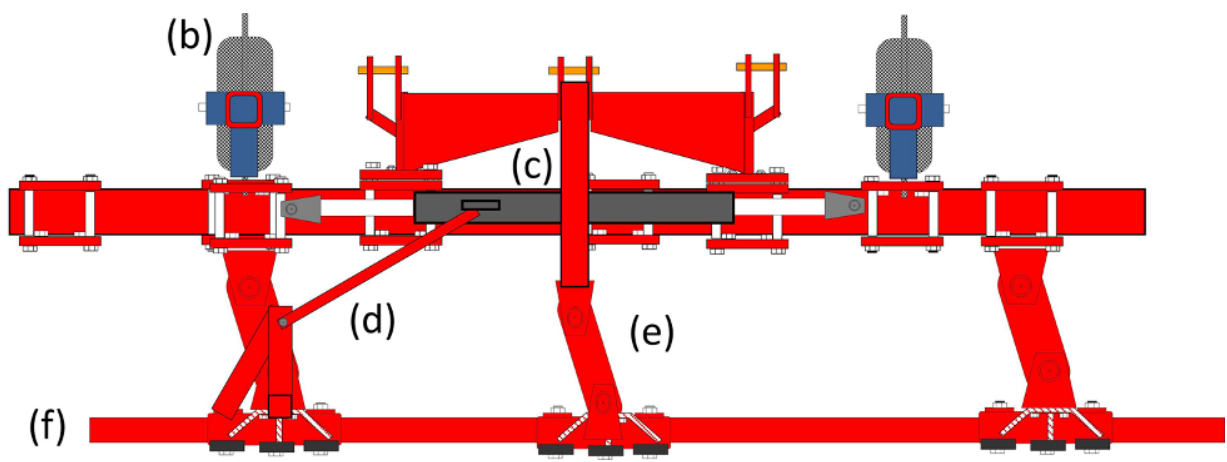


Table 1 Treatments tested in the field trials at Hohenheim $(\mathrm{HOH})$ and Ihinger Hof (IHO)

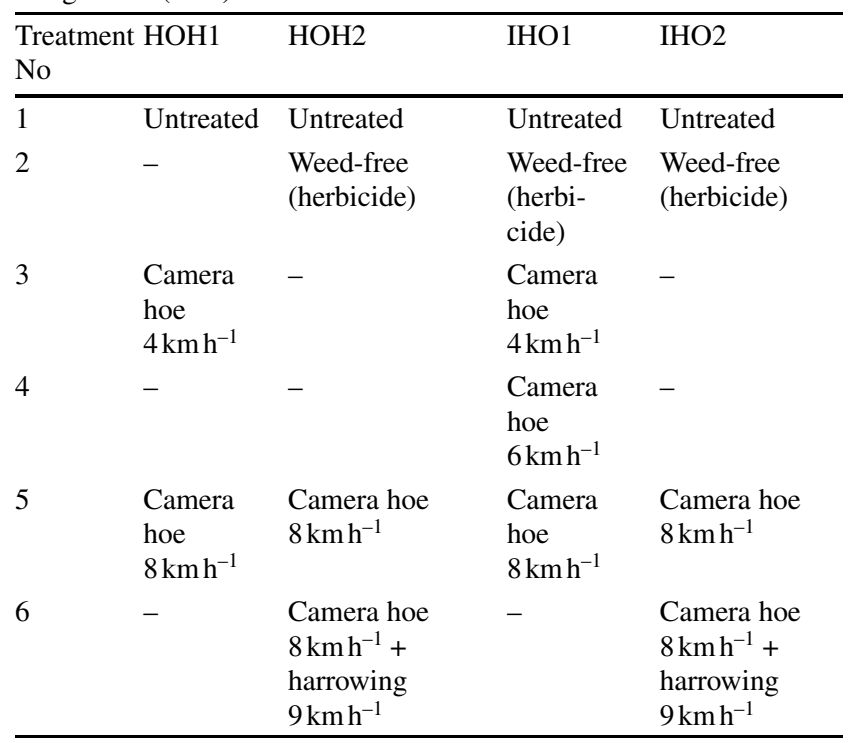

conducted in March 2019, when winter wheat had developed 3-5 tillers (BBCH23-25). In 2019, mean temperatures at both sites were $1-2^{\circ} \mathrm{C}$ higher than the long-term average (1990 2019) of $10.2^{\circ} \mathrm{C}$ at $\mathrm{HOH}$ and $9.2^{\circ} \mathrm{C}$ at IHO. It rained $80 \mathrm{~mm}$ less than the long-term average of $730 \mathrm{~mm}$ at both locations. Three days before hoeing and harrowing and two days after hoeing and harrowing, the experimental fields did not receive any precipitation.

Both field trials were set up as a randomized complete block design with different hoeing treatments as the experimental factor. Plots were $3-6 \mathrm{~m}$ wide and $12 \mathrm{~m}$ long. The treatments were randomized for each repetition. Each treatment was replicated four times. Camera-guided hoeing was tested at different speeds in two experiments (Table 1). In two experiments, a combination of camera-guided hoeing at $8 \mathrm{~km} \mathrm{~h}^{-1}$ followed by post-emergence harrowing at $9 \mathrm{~km} \mathrm{~h}^{-1}$ (6m wide) was tested with a $6 \mathrm{~m}$ wide harrow (Thomas Hatzenbichler, St. Andrä, Austria). An untreated and a herbicide control plot were established (not in $\mathrm{HOH} 1$. In the herbicide plots, $50 \mathrm{~g} \mathrm{ha}^{-1}$ Pointer WG (tribenuron methyl, 723 ga.i. $\mathrm{kg}^{-1}$, DuPont) and $500 \mathrm{~g} \mathrm{ha}^{-1}$ Atlantis ${ }^{\circledR}$ WG, $30 \mathrm{~g}$ a.i. ha $\mathrm{a}^{-1}$ mesosulfuron $+6 \mathrm{~g}$ a.i. ha ${ }^{-1}$ iodosulfuron, Bayer CropScience was sprayed in spring. The application was done with a self-propelled plot sprayer from Schachtner (Ludwigsburg, Germany). Nozzle type was a IDK 120-02 Flatfan from Lechler (Lechler, Metzingen, Germany). The pressure was set to $300 \mathrm{kpa}$ at $2001 \mathrm{ha}^{-1}$ of spray volume. The sprayer was equipped with a $3 \mathrm{~m}$ boom. At $\mathrm{HOH} 1$, only an untreated control was included.

\section{Weed Counting}

Weed density was counted immediately before and after hoeing/harrowing. Herbicide efficacy was measured 14 days after treatment. Weeds were assessed separately between the rows in a $100 \mathrm{~mm}$ wide band and within the rows in a $50 \mathrm{~mm}$ wide strip using a frame of $0.1 \mathrm{~m}^{2}$. The frame was placed at three randomly selected spots in each plot. Weed density was averaged over the three counts.

\section{Crop Soil Cover Measurement}

Crop response to weed hoeing and harrowing was measured by digital image analysis. Images were taken of the counting frames and leaf cover was computer similar to Rasmussen et al. (2008). Images were taken with a handheld camera (Sony DSC-HX60V, Sony Corp., Minato, Tokyo, Japan). The camera was equipped with an Exmor $\mathrm{R}^{\circledR}$ CMOS sensor (Sony Corp., Minato, Tokyo, Japan) with a diagonal sensor size of $7.76 \mathrm{~mm}$ and an image resolution of 20.4 million pixels. The camera was placed on a tripod with a distance of $600 \mathrm{~mm}$ to the ground. The RGB-images were transformed in the hue-saturation-value (HSV) color space. A low pass filter in the green region and a morphological filter were applied to remove all outlier colors and soil pixels. The relative area of green pixels was calculated from the segmented images.

\section{Grain Yield Determination}

Winter wheat was harvested with a $1.5 \mathrm{~m}$ plot harvester (Zürn 150, Obergurig, Germany) in an area of $15 \mathrm{~m}^{2}$. Grain samples of $500 \mathrm{~g}$ were taken from each plot to measure the grain water content. The grain yield was then adjusted to a homogeneous moisture of $14 \%$.

\section{Tacheometer Records}

The accuracy of the camera row-guidance and the hydraulic steering was determined with the robotic total station "STS930" (Trimble, Raunheim, Germany). As target the MT1000 prism was used. The tacheometer was installed in a corner outside of the test field. It measured the deviation of the hoeing blade position to the row center with an accuracy at a frequency of $4 \mathrm{~Hz}$. Six test stripes with a length of $100 \mathrm{~m}$ each were recorded, three with the $3 \mathrm{~m}$ wide hoe and three with the $6 \mathrm{~m}$ wide hoe. 


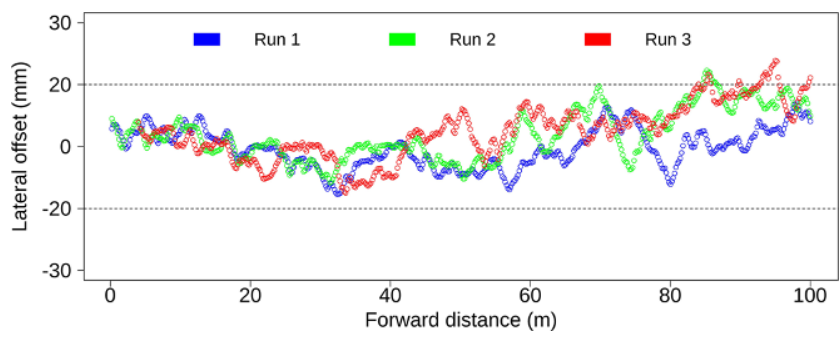

Fig. 5 Lateral offset of the camera-guided hoe with $3 \mathrm{~m}$ width. Blue points are the measured lateral positions of the first run. Green and red points mark the second and third run

\section{Data Analysis}

Weed control efficacy (WCE) was calculated according to Eq. 1.

$\mathrm{WCE}=100\left(1-w_{d s} / w_{d u}\right)$

with $w_{d s}$ representing the density of survived weeds in the treated plots and $w_{d u}$ showing the density of weeds in untreated control plots.

Crop soil cover as a measure of crop damage was calculated according to Eq. 2. It is the percentage of leaf area covered by soil directly after hoeing Rasmussen et al. (2008).

$\mathrm{CSC}=100\left(1-\mathrm{L}_{\mathrm{t}} / \mathrm{L}_{\mathrm{m}}\right)$

with $\mathrm{L}_{t}$ representing the leaf cover in treated plots. $\mathrm{L}_{m}$ is the leaf cover in the control plots.

\section{Statistical Analyses}

The statistical analysis was performed with the R Studio software (Version 1.2.1335, RStudio Team, Boston, MA, USA). Prior to analysis of variance (ANOVA), data were checked for normal distribution of the residuals and homogeneity of variance. The means were compared by Duncan's multiple range test at a level of $\alpha \leq 0.05$. For both experiments, the following linear model was used:

$y_{i j}=\mu+\beta_{j}+\tau_{i}+\mathrm{e}_{i}$

with $y_{i j}$ representing the observation of the $\mathrm{i}_{\mathrm{th}}$ treatment in the $j_{\text {th }}$ block. $\mu$ is the general mean, $\beta$ is the effect of the block j, $\tau$ is the effect of the treatment i. $e$ is the residual error.

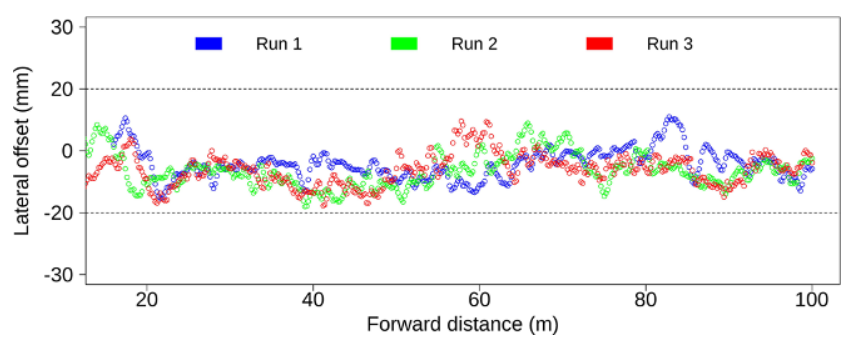

Fig. 6 Lateral offset of the segmented camera-guided hoe with $6 \mathrm{~m}$ width. Blue points are the measured lateral positions of the first run. Green and red points mark the second and third run

\section{Results}

\section{Accuracy of Camera-guided Hoeing}

For crop row distance of $150 \mathrm{~mm}$, both hoes with automatic side-shift control guided the hoeing blades precisely in the center between the crop rows until cereals had developed 5 tillers. The maximum lateral offset from the row center was $22.5 \mathrm{~mm}$ for the $3 \mathrm{~m}$ wide hoe (Fig. 5) and $18.4 \mathrm{~mm}$ for the $6 \mathrm{~m}$ wide hoe (Fig. 6, Table 2). Camera steering system was more accurate than guidance by RTK-GNSS signal, which provides accuracies of $30-40 \mathrm{~mm}$ deviation from the row center. Row detection and steering of the notill sweeps was independent on driving speed in the tested range of $3-15 \mathrm{kmh}^{-1}$.

\section{Weed Infestations}

Average weed densities before treatment ranged from 37 plants $\mathrm{m}^{-2}$ at $\mathrm{HOH} 1$ to 83 plants $\mathrm{m}^{-2}$ at $\mathrm{IHO} 2$. At $\mathrm{HOH}$, Lamium purpureum L., Veronic persica POIRET and Viola arvensis Murr were the dominant weed species. At IHO, Matricaria chamomilla L., Stellaria media (L.) VILL., L. purpureum and Alopecurus myosuroides were the most abundant weed species (Table 3).

\section{Weed Control Efficacy, Crop Soil Cover (CSC) and Grain Yields}

Camera-guided hoeing resulted in $72-96 \%$ inter-row and 21-91\% intra-row WCE. Inter-row weed control was lower than between the rows, indicating that soil burial does not sufficiently suppress weeds. Weed control was $7-15 \%$ higher at $8 \mathrm{~km} \mathrm{~h}^{-1}$ compared to $4 \mathrm{~km} \mathrm{~h}^{-1}$. WCE was increased by $14-22 \%$ in two experiments, when hoeing was followed by weed harrowing compared to one pass of hoeing alone (Table 4).

Hoeing and the combination of hoeing and harrowing buried $18-43 \%$ oft he crop leaves. CSC was slightly higher at $8 \mathrm{~km} \mathrm{~h}^{-1}$ compared to hoeing at lower speeds $\mathrm{kmh}^{-1}$. Nevertheless, the statistical analyses showed no significant differences. It was noticed that CSC after the combination of 
Table 2 Average accuracy of the row guidance recorded by the tacheometer; Standard deviation (SD) of the lateral distance to the center of the inter-row space in test strips of $100 \mathrm{~m}$ length

\begin{tabular}{llllllll}
\hline & $3 \mathrm{~m}$ width & & \multicolumn{3}{l}{ 6m width } \\
\cline { 2 - 4 } & Strip 1 & Strip 2 & Strip 3 & & Strip 1 & Strip 2 & Strip 3 \\
\hline $\begin{array}{l}\text { SD } \\
(\mathrm{mm})\end{array}$ & 18.77 & 19.16 & 22.53 & 18.42 & 18.05 & 18.28 \\
\hline
\end{tabular}

Table 3 Densities of the dominant weed species in the field experiments at Hohenheim (HOH) and Ihinger Hof (IHO)

\begin{tabular}{lll}
\hline Location & Weed Species & Density $\left(n \mathrm{~m}^{-2}\right)$ \\
\hline $\mathrm{HOH}$ & Lamium purpureum & $18.2-21.6$ \\
& Veronica persica & $4.1-6.1$ \\
& Viola arvensis & $0.7-1.0$ \\
$\mathrm{IHO}$ & Matricaria chamomilla & $22.9-24.7$ \\
& Stellaria media & $18.0-22.1$ \\
& Lamium purpureum & $10.7-15.5$ \\
& Alopecurus myosuroides & $2.8-3.2$
\end{tabular}

hoeing and harrwoing was 4-5\% lower than after hoeing. However, CSC in both treatments were statistically equal (Table 5).

Hoeing and the combination of hoeing and harrowing had a positive impact on grain yields. At both sites, grain yields were higher at $8 \mathrm{~km} \mathrm{~h}^{-1}$ than at lower speeds. Lowest yields were recorded for the untreated control plots. At IHO, hoeing increased grain yield by $50 \%$ at $4 \mathrm{~km} \mathrm{~h}^{-1}$ and $76 \%$ at $8 \mathrm{~km} \mathrm{~h}^{-1}$ compared to the untreated control. Yieds amounted the same level as the weed-free herbicide plots (Table 6).

\section{Discussion and Conclusions}

The new camera-guidance system allowed selective interrow weed hoeing in cereals with narrow row distances of $150 \mathrm{~mm}$. Lateral offset from the row center ranged from $18.1-22.5 \mathrm{~mm}$. Therefore, it was possible to use $100 \mathrm{~mm}$ wide hoeing blades between cereal rows, leaving a distance of $25 \mathrm{~mm}$ to the crop rows. Current guiding systems for weed hoeing such as Garford-Robocrop, Steketee IC,
OEM Claas (Einböck, Hatzenbichler, Schmotzer) and RTKGNSS guidance systems have a lateral offset of around $400 \mathrm{~mm}$ (Griepentrog et al. 2007; Sun et al. 2010; PerezRuiz et al. 2012). This would cause severe crop damage if the same $100 \mathrm{~mm}$ wide blades were used. So far, cameras included in automatic side-shift control systems identify crop rows based on the size of green objects in the images. Row detection would fail if crop rows overlap or many large weeds grow in the inter-row area overlapping with crop plants. Therefore, a minimum of $200 \mathrm{~mm}$ row distance was necessary in the current technologies. However, conventionally grown cereals are seeded with row distances of $125-170 \mathrm{~mm}$. Wider row distances cause yield losses due to intra-specific competition (Lötjönen and Mikkola 2000). Therefore, a different camera system and image analysis algorithm based on Tillet et al. (2002) was included in the new camera-guided hoe. This camera system detected crop rows based on density and morphology of leaves and solved the problem of partly overlapped crop leaves between cereal rows (Weis et al. 2008). The new technology worked robustly and precisely in the field studies presented. Still, problems with segmentation of plants and soil occurred under sunny and dry conditions. Those problems were solved with a parasol mounted above the camera.

Although inter-row and intra-row weed control efficacy of camera-guided hoeing in one experiment was higher than $90 \%$ and thus in the average range of the herbicide treatment, a single pass of hoeing usually provides less weed control efficacy than herbicides with soil- and leaf-activity (Machleb et al. 2018). Wet soils and advanced growth stages of weeds complicate mechanical weeding. Intra-row weed control of hoeing is always lower than inter-row weed control. Therefore, camera-guided hoeing needs to be included in a strategy of integrated weed management with different weed control tactics. Those strategies include preventive methods of weed control including wide crop rotations with spring- and autumn-sown crops, false seed bed preparation, cover cropping and living mulch or inversion tillage. Hoeing can be combined with direct weeding operations such as harrowing and the application of pre-emergence herbicide (Zoschke 1994).

Table 4 Inter-row and intra-row weed control efficacy \% (WCE) and crop soil cover \% (CSC) after treatments in the field trials at Hohenheim $(\mathrm{HOH})$ and Ihinger Hof (IHO); Means with the same letters are not significantly different according to Duncan's multiple range test $(p \leq 0.05)$. Capital letters represent significance of the inter-row space and small letters show the significance in the crop rows

\begin{tabular}{|c|c|c|c|c|c|c|c|c|}
\hline \multirow[t]{2}{*}{ Treatment } & \multicolumn{2}{|l|}{$\mathrm{HOH} 1$} & \multicolumn{2}{|l|}{$\mathrm{HOH} 2$} & \multicolumn{2}{|l|}{ IHO1 } & \multicolumn{2}{|l|}{$\mathrm{IHO} 2$} \\
\hline & Inter-row & Intra-row & Inter-row & Intra-row & Inter-row & Intra-row & Inter-row & $\overline{\text { Intra-row }}$ \\
\hline$\overline{\text { Herbicide }}$ & - & - & $98 \mathrm{~A}$ & $94 \mathrm{a}$ & $96 \mathrm{~A}$ & $91 \mathrm{a}$ & $98 \mathrm{~A}$ & $85 \mathrm{a}$ \\
\hline Camera hoe $4 \mathrm{~km} \mathrm{~h}^{-1}$ & $88 \mathrm{~A}$ & $54 \mathrm{~b}$ & - & - & $78 \mathrm{C}$ & $21 \mathrm{~b}$ & - & - \\
\hline Camera hoe $6 \mathrm{kmh}^{-1}$ & - & - & - & - & $82 \mathrm{BC}$ & $25 \mathrm{~b}$ & - & - \\
\hline Camera hoe $8 \mathrm{~km} \mathrm{~h}^{-1}$ & $96 \mathrm{~A}$ & $91 \mathrm{a}$ & $79 \mathrm{~B}$ & $22 \mathrm{c}$ & $92 \mathrm{AB}$ & $31 \mathrm{~b}$ & $72 \mathrm{C}$ & $64 \mathrm{~b}$ \\
\hline $\begin{array}{l}\text { Camera hoe } 8 \mathrm{~km} \mathrm{~h}^{-1}+\text { har- } \\
\text { rowing } 9 \mathrm{kmh}^{-1}\end{array}$ & - & - & $89 \mathrm{AB}$ & $44 \mathrm{~b}$ & - & - & $83 \mathrm{~B}$ & $78 \mathrm{ab}$ \\
\hline
\end{tabular}


Table 5 Crop soil cover \% (CSC) immediately after mechanical weed control at Hohenheim $(\mathrm{HOH})$ and Ihinger Hof (IHO). Means with different letters are significantly different according to Duncan's multiple range test $(p \leq 0.05)$

\begin{tabular}{lllll}
\hline & HOH1 & HOH2 & IHO1 & IHO2 \\
\hline Camera hoe $4 \mathrm{~km} \mathrm{~h}^{-1}$ & $37 \mathrm{a}$ & N/A & $18 \mathrm{a}$ & N/A \\
Camera hoe $6 \mathrm{~km} \mathrm{~h}^{-1}$ & N/A & N/A & $21 \mathrm{a}$ & N/A \\
Camera hoe $8 \mathrm{~km} \mathrm{~h}^{-1}$ & $43 \mathrm{a}$ & $34 \mathrm{a}$ & $25 \mathrm{a}$ & $26 \mathrm{a}$ \\
Camera hoe $8 \mathrm{~km} \mathrm{~h}^{-1}+$ & N/A & $29 \mathrm{a}$ & N/A & $22 \mathrm{a}$ \\
harrowing $9 \mathrm{~km} \mathrm{~h}^{-1}$ & & & & \\
\hline
\end{tabular}

N/A not applicable

Table 6 Grain yields $\left(\mathrm{tha}^{-1}\right)$ at Hohenheim $(\mathrm{HOH})$ and Ihinger Hof (IHO) after camera-guided hoeing at different speeds and in combination with harrowing. Means with different letters are significantly different according to Duncan's multiple range test $(p \leq 0.05)$

\begin{tabular}{lllll}
\hline & HOH1 & HOH2 & IHO1 & IHO2 \\
\hline Untreated & $4.0 \mathrm{a}$ & $6.8 \mathrm{a}$ & $6.5 \mathrm{a}$ & $6.4 \mathrm{a}$ \\
Herbicide & N/A & $7.8 \mathrm{a}$ & $7.5 \mathrm{~b}$ & $7.4 \mathrm{a}$ \\
Camera hoe $4 \mathrm{~km} \mathrm{~h}^{-1}$ & $6.0 \mathrm{~b}$ & N/A & $7.0 \mathrm{ab}$ & N/A \\
Camera hoe $6 \mathrm{~km} \mathrm{~h}^{-1}$ & N/A & N/A & $6.8 \mathrm{ab}$ & N/A \\
Camera hoe $8 \mathrm{~km} \mathrm{~h}^{-1}$ & $7.1 \mathrm{c}$ & $7.2 \mathrm{a}$ & $7.5 \mathrm{~b}$ & $6.9 \mathrm{a}$ \\
Camera hoe & N/A & $7.0 \mathrm{a}$ & N/A & $7.2 \mathrm{a}$ \\
$8 \mathrm{kmh}^{-1}+$ & & & & \\
harrowing $9 \mathrm{~km} \mathrm{~h}^{-1}$ & & & & \\
\hline
\end{tabular}

N/A not applicable

Kunz et al. (2015) measured 15\% higher weed control efficacy with automatic side-shift hoes compared to manual hoeing in sugar beet and soybean. With precise steering systems, hoeing blades can be moved closer along crop rows increasing the treated area and reducing crop damage. Weed control efficacy was higher in the intra-row area, when camera-guidance was use compared to manual steering systems (Kunz et al. 2015). This was probably an effect of more soil movement into the rows and stronger weed burial due to higher driving speeds (Kunz et al. 2015). Higher weed control efficacy and lower crop damage due to precise steering increases selectivity of weed hoeing.

In conclusion, the new automatic steering technology for inter-row weed hoeing provides a strong alternative to chemical weed control in conventional cereals production. It is an additional tool in order to solve problems caused by herbicide resistant weed species and herbicides residues in the food chain.

Funding Open Access funding enabled and organized by Projekt DEAL.

Conflict of interest R. Gerhards, B. Kollenda, J. Machleb, K. Möller, A. Butz, D. Reiser and H.-W. Griegentrog declare that they have no competing interests.

Open Access This article is licensed under a Creative Commons Attribution 4.0 International License, which permits use, sharing, adapta- tion, distribution and reproduction in any medium or format, as long as you give appropriate credit to the original author(s) and the source, provide a link to the Creative Commons licence, and indicate if changes were made. The images or other third party material in this article are included in the article's Creative Commons licence, unless indicated otherwise in a credit line to the material. If material is not included in the article's Creative Commons licence and your intended use is not permitted by statutory regulation or exceeds the permitted use, you will need to obtain permission directly from the copyright holder. To view a copy of this licence, visit http://creativecommons.org/licenses/by/4. $0 /$.

\section{References}

Blair AM, Jones PA, Orson JH, Caseley JC (1997) Integration of row widths, chemical and mechanical weed control and the effect on winter wheat yield. In: Aspects of Applied Biology 50, Optimising Cereal Inputs: Its Scientific Basis. Part 2, Crop Protection and Systems, pp 385-392

Brandsaeter LO, Mangerud K, Rasmussen J (2012) Interactions between pre- and post-emergence weed harrowing in spring cereals. Weed Res 52:338-347

Dierauer HU, Stöppler-Zimmer H (1994) Unkrautregulierung ohne Chemie. Ulmer, Stuttgart

Gerhards R (2010) Unkrautkontrolle in Weizen. In: Christen O (ed) Handbuch zu Weizen. DLG-Verlag, Frankfurt

Griepentrog HW, Noerremark M, Nielsen J, Soriano Ibarra J (2007) Autonomous inter-row hoeing using GPS based side-shift control. Agric Eng Int Cigr Ejournal 9:9 (Manuscript ATOE 07 005)

Hammarström L, Gillberg B, Pettersson H (1993) Inter-row cultivation in cereals. Communications of the Fourth Conference IFOAM-Non-Chemical Weed Control, Dijon, pp 315-317

Håkansson S (1984) Row spacing, seed distribution in the row, amount of weeds-influence on production in stands of cereals. Weeds and weed control 25th Swedish Weed Conference, Uppsala, pp 17-34

Kunz C, Weber JF, Peteinatos GG et al (2018) Camera steered mechanical weed control in sugar beet, maize and soybean. Precis Agric 19:708-720

Kunz C, Weber JF, Gerhards R (2015) Benefits of precision farming technologies for mechanical weed control in soybean and sugar beet - comparison of precision hoeing with conventional mechanical weed control. Agronomy 5:130-142

Lötjönen T, Mikkola HJ (2000) Three mechanical weed control techniques in spring cereals. Agric Food Sci Finl 9:269-278

Machleb J, Kollenda B, Peteinatos G, Gerhards R (2018) Adjustment of weed hoeing to narrowly spaced cereals. Agriculture 8:54

Massa D, Kaiser YI, Andújar-Sánchez D, Carmona-Alférez R, Mehrtens J, Gerhards R (2013) Development of a Geo-referenced database for weed mapping and analysis of agronomic factors affecting herbicide resistance in Apera spica-venti L. Beauv. (silky windgrass). Agronomy 3:13-27

Melander B (2006) Current achievements and future directions of physical weed control in Europe. AFPP 3rd International conference on non-chemical crop protection methods, Lille, 13-15 March, pp 49-58

Melander B, Cirujeda A, Jørgensen MH (2003) Effects of inter-row hoeing and fertilizer placement on weed growth and yield of winter wheat. Weed Res 43:428-438

Mülle G, Heege HJ (1981) Kornverteilung über die Fläche und Ertrag bei Getreide. Z Acker Pflanzenbau 150:97-112

Perez-Ruiz M, Slaughter DC, Gliever C, Upadhyaya S (2012) Tractor-based Realtime Kinematic-Global Positioning System (RTKGPS) guidance system for geospatial mapping of row crop transplants. Biosyst Eng 111(1):64-71 
Rasmussen IA (2004) The effect of sowing date, stale seedbed, row width and mechanical weed control on weeds and yields of organic winter wheat. Weed Res 44:12-20

Rasmussen J, Ascard J (1995) Weed control in organic farming systems. In: Glen DM, Greaves MP, Anderson HM (eds) Ecology and integrated farming systems. John Wiley \& Sons, Chichester, pp 49-67

Rasmussen J, Svenningsen T (1995) Selective weed harrowing in cereals. Biol Agric Hortic 12:29-46

Rasmussen J, Bibby BM, Schou AP (2008) Investigating the selectivity of weed harrowing with new methods. Weed Res 48:523-532

Soegaard HT, Olsen HJ (2003) Determination of crop rows by image analysis without segmentation. Comput Electron Agric 38:141-158

Sun H, Slaughter DC, Perez-Ruiz M, Gliever C, Upadhyaya SK, Smith RF (2010) RTK GPS mapping of transplanted row crops. Comput Electron Agric 71(1):32-37
Tillett ND, Hague T (1999) Computer-vision-based hoe guidance for cereals-An initial trial. J Agric Eng Res 74:225-236

Tillett ND, Hague T, Miles SJ (2002) Inter-row vision guidance for mechanical weed control in sugar beet. Comput Electron Agric 33:163-177

Weis M, Gutjahr C, Rueda-Ayala V, Gerhards R, Ritter C, Schölderle F (2008) Precision farming for weed management: techniques. Gesunde Pflanz 60(4):171-180

Zoschke A (1994) Toward reduced herbicide rates and adapted weed management. Weed Technol 8:376-386

Roland Gerhards has been head of the Department of Herbology at the University of Hohenheim since 2004. In research he is engaged in precision farming methods to control weeds in arable and vegetable crops and to reduce the use of herbicides. 